bioRxiv preprint doi: https://doi.org/10.1101/745018; this version posted August 22, 2019. The copyright holder for this preprint (which was not certified by peer review) is the author/funder, who has granted bioRxiv a license to display the preprint in perpetuity. It is made available under aCC-BY 4.0 International license.

Ciano et al

\title{
Haploinsufficient maternal effect of Epidermal Growth Factor Receptor A mutation in zebrafish
}

2

Margherita Ciano ${ }^{1,20 R C I D}$, Paul R. Kemp ${ }^{3}$, S. Amanda Sathyapala ${ }^{30 R C I D}$ and Simon M. Hughes ${ }^{10 R C I D *}$

${ }^{1}$ Randall Centre for Cell and Molecular Biophysics, King's College London, London UK.

2 Department of Medicine, Imperial College London, London UK

${ }^{3}$ National Heart and Lung Institute, Imperial College London, London UK

*Author for correspondence s.hughes@kcl.ac.uk

Randall Centre for Cell and Molecular Biophysics, New Hunt's House, Guy's Campus, King's College London, SE1 1UL, UK

\section{Abstract}

Generation of viable offspring depends both on genetic and environmental factors of both mother and child. Analysis of a likely amorphic allele of the zebrafish epidermal growth factor receptor a (egfra) gene revealed that heterozygous females were infertile due to death of all fertilized eggs during embryonic and early larval life with cardiac, tail and other defects. Comparison of the severe dominant maternal effect with previous studies using pharmacological inhibitors of Egfrs or antisense morpholino injection indicate that a normal level of maternal Egfra is required for viability of offspring both during egg development and in the embryo after fertilisation. As heterozygous mothers were not fertile, the homozygous zygotic egfrakg134 phenotype could not be analysed. Heterozygous egfra ${ }^{+/ k g 134}$ males crossed to wild type females produced fully viable offspring, among which egfra ${ }^{+/ k g 134}$ individuals had increased slow muscle but no functional motility defect. Our findings suggest that Egfra activity is crucial for early development both before and after fertilisation and are likely to constitute a rare example of a haploinsufficient maternal effect in a species lacking imprinting.

\section{Introduction}

Regulation of fertility is important for humans and food production. Development of oocytes and early embryos depends on the contribution of protein and RNA encoded by the maternal genome prior to the final meiotic division to yield the mature gamete. Maternal effect genetic screens have been a powerful tool in unravelling early embryo development across vertebrates (Marlow, 2010). A particularly important aspect of oocyte development is its interaction with other cells within the ovary, such as follicular or nurse cells, which are mediated by a wide range of reciprocal extracellular signals (Richani and Gilchrist, 2018). Mutation of genes required for such signals have been shown to have effects on the developing oocyte or embryo when the mother is homozygous for the mutation, irrespective of ultimate embryonic genotype (Marlow, 2010). In general, however, maternal effect mutations are recessive, such that heterozygous females yield offspring that develop normally unless the offspring inherit an allelic combination causing a zygotic phenotype. Here we describe dominant maternal effect caused by mutation in the zebrafish egfra gene.

Epidermal growth factor (EGF) signalling through EGFR receptors of the ErbB family is of central importance in human reproduction (Richani and Gilchrist, 2018). In mammals, several EGFR ligands and 
bioRxiv preprint doi: https://doi.org/10.1101/745018; this version posted August 22, 2019. The copyright holder for this preprint (which was not certified by peer review) is the author/funder, who has granted bioRxiv a license to display the preprint in perpetuity. It is made available under aCC-BY 4.0 International license.

Ciano et al

the EGFR itself are required for oocyte maturation and ovulation (Hsieh et al., 2007). The EGFR is not thought to be present on the oocyte itself, but acts via the surrounding cumulus cells, in which EGFR signalling triggers expansion of the cumulus and cumulus-derived extracellular matrix and promotes oocyte maturation through downregulation of cyclic nucleotides that are shared with the oocyte through gap junctions and suppress meiotic resumption. EGFR signaling within the follicle also enhances oocyte ATP production and subsequent oocyte developmental competence (that is, the ability of an oocyte to yield, upon fertilization, an embryo that successfully develops to term; (Richani and Gilchrist, 2018) and references therein). Indeed, levels of the EGFR ligand Amphiregulin in follicles correlate with infertility and successful IVF treatment (Ambekar et al., 2015; Huang et al., 2015). Strikingly, in mouse, maturation of EGFR signalling competence in cumulus cells is itself triggered by oocyte-derived signals, supporting the view that stepwise maturation of the follicle involves continual crosstalk between oocyte and its support cells that modulate EGFR signaling (Richani and Gilchrist, 2018). It is, therefore, of great importance to understand the roles of EGFR in oocyte maturation and acquisition of developmental competence.

EGF signalling has been extensively characterized in cultured cells and in mammals, in large part due to its importance in a variety of cancers (https://omim.org/entry/131550). During murine development, Egfr is an essential gene; null mutation leads to genetic background-dependent prenatal death due to placental insufficiency, and additional lung, epidermis, whisker and eye defects (Miettinen et al., 1995; Sibilia and Wagner, 1995; Threadgill et al., 1995). Numerous other mutant alleles affect hair and skin and cause defects in a variety of organs including heart and lung. However, genetic loss of function analysis in vertebrates beyond the mouse has not been performed.

In the zebrafish, egfra function has been implicated in cardiac outflow tract formation, aorta thickness, adult intestinal adaptation and ovarian follicle development (Aizen and Thomas, 2015; Goishi et al., 2003; Peyton and Thomas, 2011; Schall et al., 2015; Wang and Ge, 2004; Zhao and Lin, 2013). In embryos/larvae, inhibition of zebrafish Egfra with either AG1478 or PK166, two drugs that inhibit mammalian EGFRs, leads to death from pericardial oedema, an effect that can be phenocopied by egfra antisense morpholino injection (Goishi et al., 2003). We previously described generation of the putative null egfrakg134 allele in the zebrafish in which a frameshift 12 amino acids from the $\mathrm{N}$-terminus of the protein leads to a severe truncation. Heterozygous egfra ${ }^{+/ k g 134}$ larvae have a mild increase in slow muscle but are viable, whereas homozygous mutants die early in larval life (Ciano et al., 2019). However, in our initial report, more extensive analysis of the genetics of the egfrakg134 allele was not reported.

Here we analyse the genetics of the egfra loss of function mutation in more detail and report the striking finding that the egfrakg134 allele shows a maternal effect in heterozygous mothers, such that no offspring survive beyond early larval life, irrespective of zygotic genotype. In contrast, heterozygous males yield viable heterozygous offspring of both sexes.

\section{Results}

The egfra mutant allele egfra ${ }^{k g 134}$ generated by CRISPR/Cas9 genome editing has a small indel that leads to a frameshift after 12 amino acids in the first coding exon. This results in termination of the resultant polypeptide with a 70 amino acid nonsense tail at a normally out-of-frame stop codon in the second coding exon (Ciano et al., 2019). The predicted protein lacks essential EGF binding regions, the transmembrane domain and the intracellular tyrosine kinase of EGFR and is therefore highly unlikely to have any residual 
bioRxiv preprint doi: https://doi.org/10.1101/745018; this version posted August 22, 2019. The copyright holder for this preprint (which was not certified by peer review) is the author/funder, who has granted bioRxiv a license to display the preprint in perpetuity. It is made available under aCC-BY 4.0 International license.

Ciano et al

positive or dominant negative function. Further evidence for lack of a dominant negative effect is a) that the mutant allele causes nonsense-mediated mRNA decay, so little truncated protein will be produced (Ciano et al., 2019) and b) that heterozygous egfra ${ }^{+/ k g 134}$ larvae do not show any of the severe defects reported in Egfr null mutant mice (Miettinen et al., 1995; Sibilia and Wagner, 1995; Threadgill et al., 1995).

\section{Fertilized eggs from egfra ${ }^{+/ k g 134}$ heterozygous females die early}

Heterozygous F1 egfra ${ }^{+/ k g 134}$ fish were in-crossed to generate embryos homozygous for the mutation. However, all embryos died in the lays. Four F1 egfra ${ }^{+/ k g 134}$ in-crosses between the single available adult F1 carrier egfra ${ }^{+/ k g 134}$ female (designated $\alpha$ ) and different egfra ${ }^{+/ k g 134} \mathrm{~F} 1$ males were performed. No embryos survived beyond 4 days post fertilisation (dpf). Most deaths occurred between 1 and $2 \mathrm{dpf}$ (Fig. 1A). Genotyping of resultant F2 embryos failed to reveal differences based on zygotic genotype.

F2 generations were bred by out-crossing carrier egfra ${ }^{+/ k g 134}$ males to wild type females. After genotyping to identify egfra ${ }^{+/ k g 134} \mathrm{~F} 2$ males and females, three females (designated $\beta, \gamma$ and $\delta$ ) and various males were obtained. Repeatedly, embryos laid by F2 egfra ${ }^{+/ k g 134}$ females all died (Fig. 1B). In contrast, embryos laid from wild type egfra ${ }^{+/+}$sibling F2 females developed normally and survived (Fig. 1B). Paternal genotype had no discernible effect; fertilisation of wild type-derived eggs by sperm from either wild type or egfra ${ }^{+/ k g 134} \mathrm{~F} 2$ sibling males yielded viable embryos (Fig. 1B). An F3 generation was bred by out-crossing an egfrat/kg134 F2 male to a wild type female. Female F3 egfra ${ }^{+/ k g 134}$ carriers again failed to yield viable offspring (data not shown). The number of eggs produced by egfra ${ }^{+/ k g 134}$ females was not significantly different from that produced by their wild type siblings. These data suggest that female zebrafish possessing only a single functional egfra allele are not fertile because they produce eggs that cannot develop normally.

\section{Heterozygous maternal effect causes abnormal embryo development}

Maternal effect is often caused by the requirement of gene function in the egg or fertilized embryo from mRNA placed in the egg during oogenesis (Marlow, 2010). We performed in situ mRNA hybridization on newly-laid eggs and embryos prior to activation of the zygotic genome and observed egfra mRNA accumulation in the early embryos (Fig. 2A). This finding indicates that egfra mRNA derived from maternal chromosomes is accumulated in the egg.

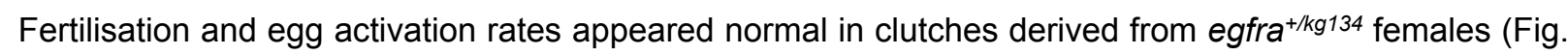
1). Chorion elevation was indistinguishable from wild type (data not shown). Although small numbers of unfertilized embryos were observed in some lays, as reflected by the slight drop in survival during the first dpf in some control lays (Fig. 1B), such unfertilized embryos were readily distinguished from fertilized embryos undergoing cleavage in lays from egfra ${ }^{+/ k g 134}$ females. No defects in cleavage stage development were noted. Moreover, epiboly and gastrulation were not grossly defective (data not shown). By $18 \mathrm{hpf}$, however, almost all embryos in clutches from egfra ${ }^{+/ k g 134}$ females were defective (Fig. 2B). Subsequently, a range of defects of variable severity appeared. Moderately affected embryos had a curved tail tip sometimes accompanied by cardiac oedema. 'Severe' embryos had unusual yolk shapes and showed altered tailbud morphology and poor yolk extension. Very severely affected embryos lacked a tail and showed signs compatible with widespread apoptosis (Fig. 2B). The severity of defects did not correlate with zygotic egfra genotype. For example, the moderately affected embryo shown in Fig. 2B was a zygotic mutant derived from an egfra ${ }^{+/ k g 134}$ female crossed to an egfra ${ }^{+/ k g 134}$ male. In contrast, more severely defective embryos could be 
bioRxiv preprint doi: https://doi.org/10.1101/745018; this version posted August 22, 2019. The copyright holder for this preprint (which was not certified by peer review) is the author/funder, who has granted bioRxiv a license to display the preprint in perpetuity. It is made available under aCC-BY 4.0 International license.

Ciano et al

egfra ${ }^{+/ k g 134}$ or wild type, whether derived from a heterozygote in-cross or an egfra ${ }^{+/ k g 134}$ female crossed to a wild type male (Fig. 2B and data not shown). We conclude that reduction of Egfra function derived from the mother causes a severe developmental defect.

\section{Behaviour of mutant and wild type larvae}

To examine the role of zygotic egfra further, bearing in mind the increase in slow muscle fibres previously observed (Ciano et al., 2019), differences in burst swimming in response to touch were investigated in F3 egfra ${ }^{+/ k g 134}$ and wt siblings. No significant difference in motility were observed (Fig. 3). Heterozygous egfra $^{+/ k g 134}$ and wt sibling larvae grew to adulthood equally well and were indistinguishable as adults (data not shown).

\section{Discussion}

The data presented strongly suggest that egfra has an essential role on early embryonic development and that the level of the expressed Egfra receptor is crucial. As we have only isolated and characterised a single mutant allele, we cannot rule out the possibility that the sgRNA used generated an off-target mutation closely-linked to the egfrakg134 allele on chromosome 2 . We think this unlikely because i) no close matches with adjacent PAM sites are present nearby on chromosome 2 (CRISPRdirect shows zero 20 bp or 12 bp matches and the nearest $7 / 8$ bp seed match with an adjacent PAM site are $3 \mathrm{Mb}$ distal and $1.5 \mathrm{Mb}$ proximal on chromosome 2 and neither lies in or near a known coding region), ii) two other lines with F1s carrying distinct egfra mutant alleles generated with the same sgRNA did not yield fertile F1 females and were discarded before the nature of the maternal effect became apparent, iii) egfra is expressed in the developing oocyte, egg and early embryo, consistent with a maternal effect (Goishi et al., 2003), and iv) Egfr has previously been implicated in oocyte development in zebrafish (Peyton and Thomas, 2011; Van Der Kraak and Lister, 2011).

The correct level of the Egfra receptor appears to be important for zebrafish fertility. We previously reported that egfra mRNA is reduced by $50 \%$ in egfra ${ }^{+/ k g 134}$ fish (Ciano et al., 2019), consistent with nonsense mediated decay of the mutant mRNA, bearing in mind that the minor sequence change in exon 1 is not predicted to affect transcription, splicing, or translational initiation. It is therefore likely that during some or all of egg development and early embryonic life, Egfra protein level in the developing gamete/embryo may be reduced. It has been suggested that oocyte maturation depends on the balance of Egfr (also known as Erbb1) and other Erbb receptors, such as Erbb2, that can heterodimerise (Aizen et al., 2018). Other work has suggested a role for Egfr activity in the follicle cells during oocyte maturation in zebrafish (Wang and Ge, 2004) and ovulation in mice (Ashkenazi et al., 2005; Hsieh et al., 2007; Jamnongjit et al., 2005). Treatment of female fish with the environmental dioxin pollutant TCDD reduces both fertility and egfra level in the ovary (Heiden et al., 2008). However, we observe normal egg abundance, mating behaviour, fertilisation rates and oocyte activation from egfra ${ }^{+/ k g 134}$ females. Moreover, early stages of cleavage and epiboly also appear normal. Our egfra ${ }^{k g 134}$ maternal effect mutation has late and pleiotropic effects. We therefore hypothesise that the relevant period for the requirement for the correct level of Egfra may extend into early embryonic life. But an alternative possibility is that lack of appropriate EGFR signalling during oocyte development reduces oocyte quality such that subsequent embryo development is compromised. The fact that injection of egfratargeting morpholino antisense oligonucleotides into 1-cell stage embryos does not phenocopy the 
bioRxiv preprint doi: https://doi.org/10.1101/745018; this version posted August 22, 2019. The copyright holder for this preprint (which was not certified by peer review) is the author/funder, who has granted bioRxiv a license to display the preprint in perpetuity. It is made available under aCC-BY 4.0 International license.

Ciano et al

egfra $^{+/ k g 134}$ maternal effect (Goishi et al., 2003), suggests the maternal Egfra protein functions before fertilisation and/or may be stockpiled in the egg.

Our data add an evolutionary perspective to the increasing understanding of the importance of EGFR signalling in mammalian oocyte development (Richani and Gilchrist, 2018). Our data show that reduction of maternal Egfra function generates poor quality eggs, irrespective of zygotic genotype. Despite fertilisation and apparently normal cleavage, embryos from egfra ${ }^{+/ k g 134}$ mothers develop poorly and die. In humans and other mammals, oocyte maturation and high oocyte developmental competence depend on EGFR signalling within the follicle that acts on cumulus cells and may affect in vitro maturation procedures that could offer significant benefit to women with polycystic ovary syndrome or cancer (Richani and Gilchrist, 2018). Such signalling is thought to enhance metabolic capacity and regulate post-transcriptional events that prepare oocytes for their future developmental role in the embryo (Chen et al., 2013; Richani et al., 2014; Sugimura et al., 2015). Our finding that EGFR signalling controls developmental competence in zebrafish suggests that EGFR signalling is an ancient and important pathway in oogenesis that is conserved across vertebrate evolution.

Treatment of zebrafish embryos with Egfr-blocking drugs causes a variety of defects (Budi et al., 2008; Goishi et al., 2003), but those described are not as severe as the early death we observe. This supports the view that Egfra activity is required both prior to egg laying for correct egg development and after egg laying for later developmental steps. Morpholino knockdown of Egfra leads to cardiac and vascular abnormalities that have some similarities to the variable penetrance cardiac oedema we observe (Goishi et al., 2003). Altered Egfra activity has also been described to cause biliary atresia and to alter gut repair (Ningappa et al., 2015; Schall et al., 2015), processes that may contribute the phenotypes we observe, but are unlikely to cause the gross embryonic defects and early death.

We also report further characterisation of the phenotype of egfra ${ }^{+/ k g 134} \mathrm{fish}$, which have extra slow muscle fibres in their somitic myotome (Ciano et al., 2019). These egfra ${ }^{+/ k g 134}$ fish did not change speed of swimming triggered by a touch, a validated physiological measure that is fast fibre-dependent (Naganawa and Hirata, 2011). As the level of Hedgehog ( $\mathrm{Hh}$ ) signaling also controls the number of slow muscle fibres in zebrafish somite, it is possible that the EGF-repeat containing protein Scube2, which is required for normal slow fibre formation could provide a link to EGF/Egfr function (Blagden et al., 1997; Hollway et al., 2006). However, because Scube2 lacking the EGF domains can rescue $\mathrm{Hh}$ palmitoylation and signaling in vitro and in vivo (Creanga et al., 2012), it is unclear if reduction of Egfra function affects slow myogenesis through modulating $\mathrm{Hh}$ signalling. Alternatively, Egfra function may suppress the later $\mathrm{Hh}$-independent additional slow myogenesis, as patterned expression is observed in the somite after $1 \mathrm{dpf}$ (Fig. 2B)(Barresi et al., 2001; Ciano et al., 2019). To date we have been unable to discern a zygotic functional phenotype in egfra ${ }^{+/ k g 134}$ fish. Unfortunately, egfrakg134 homozygote mutants do not survive well or long enough for meaningful functional studies.

Finally, the most notable aspect of our findings is the existence of such a highly penetrant heterozygous maternal effect that we attribute to haploinsufficiency. Female mice lacking one allele of Egfr do not show a similar infertility (Miettinen et al., 1995; Sibilia and Wagner, 1995; Threadgill et al., 1995). To our knowledge, few dominant maternal effect genes have been described, although many may have been discarded in the extensive screens for recessive zygotic and maternal effect mutations (Marlow, 2010). Rare known examples of maternal haploinsufficiency are the unmapped mel-23 $3^{\mathrm{ct} 45}$ allele in $\mathrm{C}$. elegans and the Minute 
bioRxiv preprint doi: https://doi.org/10.1101/745018; this version posted August 22, 2019. The copyright holder for this preprint (which was not certified by peer review) is the author/funder, who has granted bioRxiv a license to display the preprint in perpetuity. It is made available under aCC-BY 4.0 International license.

Ciano et al

allele RpS174 in D. melanogaster (Boring et al., 1989; Mains et al., 1990). In mammals, genetics mimicking maternal haploinsufficiency can be observed after uneven X-chromosome inactivation or in imprinted genes where the paternal allele is not expressed. However, zebrafish have neither sex chromosomes, nor parental imprinting. Moreover, because we used genome editing to create and select egfrakg134 as a likely loss of function egfra allele, we suggest that the apparent dominant maternal effect is caused by maternal haploinsufficiency of Egfra. Although to date searches of OMIM and extant QTL data have failed to reveal linkage of human EGFR variation to infertility, a possible genetic influence on EGFR signalling in fertility in humans and other vertebrates should be borne in mind.

\section{Methods}

\section{Zebrafish lines and maintenance}

218 Zebrafish were reared at King's College London on a $14 / 10$ hours light/dark cycle at $28.5^{\circ} \mathrm{C}$ with adults kept 219 at $26.5^{\circ} \mathrm{C}$, with staging and husbandry as described (Westerfield, 2000). Founder and subsequent 220 generations were out-crossed to AB fish. Fish were genotyped by High Resolution Melt Analysis and/or DNA 221 sequencing in the mutant alleles, following PCR amplification using primers indicated (Supplementary Table

222 1). Individual genotyped carrier egfra ${ }^{k g 134 /+}$ females were kept in separate tanks to ensure reproducibility. All experiments were performed in accordance with licences held under the UK Animals (Scientific Procedures) Act 1986 and later modifications and conforming to all relevant guidelines and regulations.

Imaging and in situ mRNA hybridization

ISH was performed as described (Ganassi et al., 2014). Briefly, fish were fixed in $4 \%$ paraformaldehyde (PFA) in phosphate-buffered saline (PBS) for $30 \mathrm{~min}$ or 3 hours at room temperature, stored in $100 \%$ methanol at $-20^{\circ} \mathrm{C}$ and rehydrated in PBS prior to ISH. Digoxigenin-labelled probes were against egfra as described (Ciano et al., 2019) and embryos were imaged under a Leica MZ16F with Olympus camera.

\section{Motility Assay}

233 Embryos touch response was measured on F3 larvae at 2 and $5 \mathrm{dpf}$ and recorded with a Leica DFC490 colour camera at 500 frame per seconds, as previously described (Naganawa and Hirata, 2011). Each embryo was imaged in a petri dish of fish water under a Leica MZ16F microscope, the tail touched with forceps to trigger movement and behaviour recorded for $10 \mathrm{~s}$. Videos were analysed blind with Tracker software 4.97 (https://physlets.org/tracker/) and mean and maximum velocity calculated. DNA was subsequently extracted from each embryo for genotyping.

\section{References}

Aizen, J., Pang, Y., Harris, C., Converse, A., Zhu, Y., Aguirre, M. A. and Thomas, P. (2018). Roles of progesterone receptor membrane component 1 and membrane progestin receptor alpha in regulation of zebrafish oocyte maturation. Gen Comp Endocrinol 263, 51-61. 
bioRxiv preprint doi: https://doi.org/10.1101/745018; this version posted August 22, 2019. The copyright holder for this preprint (which was not certified by peer review) is the author/funder, who has granted bioRxiv a license to display the preprint in perpetuity. It is made available under aCC-BY 4.0 International license.

Ciano et al

Aizen, J. and Thomas, P. (2015). Role of Pgrmc1 in estrogen maintenance of meiotic arrest in zebrafish oocytes through Gper/Egfr. J Endocrinol 225, 59-68.

Ambekar, A. S., Kelkar, D. S., Pinto, S. M., Sharma, R., Hinduja, I., Zaveri, K., Pandey, A., Prasad, T. S., Gowda, H. and Mukherjee, S. (2015). Proteomics of follicular fluid from women with polycystic ovary syndrome suggests molecular defects in follicular development. J Clin Endocrinol Metab 100, 744-753.

Ashkenazi, H., Cao, X., Motola, S., Popliker, M., Conti, M. and Tsafriri, A. (2005). Epidermal growth factor family members: endogenous mediators of the ovulatory response. Endocrinology 146, 77-84.

Barresi, M. J., D'Angelo, J. A., Hernandez, L. P. and Devoto, S. H. (2001). Distinct mechanisms regulate slow-muscle development. Current biology : CB 11, 1432-1438.

Blagden, C. S., Currie, P. D., Ingham, P. W. and Hughes, S. M. (1997). Notochord induction of zebrafish slow muscle mediated by Sonic Hedgehog. Genes Dev 11, 2163-2175.

Boring, L. F., Sinervo, B. and Schubiger, G. (1989). Experimental phenocopy of a minute maternal-effect mutation alters blastoderm determination in embryos of Drosophila melanogaster. Dev Biol 132, 343-354.

Budi, E. H., Patterson, L. B. and Parichy, D. M. (2008). Embryonic requirements for ErbB signaling in neural crest development and adult pigment pattern formation. Development 135, 2603-2614.

Chen, J., Torcia, S., Xie, F., Lin, C. J., Cakmak, H., Franciosi, F., Horner, K., Onodera, C., Song, J. S., Cedars, M. I., et al. (2013). Somatic cells regulate maternal mRNA translation and developmental competence of mouse oocytes. Nat Cell Biol 15, 1415-1423.

Ciano, M., Mantellato, G., Connolly, M., Paul-Clark, M., Willis-Owen, S., Moffatt, M. F., Cookson, W., Mitchell, J. A., Polkey, M. I., Hughes, S. M., et al. (2019). EGF receptor (EGFR) inhibition promotes a slow-twitch oxidative, over a fast-twitch, muscle phenotype. Scientific reports $\mathbf{9}, 9218$.

Creanga, A., Glenn, T. D., Mann, R. K., Saunders, A. M., Talbot, W. S. and Beachy, P. A. (2012). Scube/You activity mediates release of dually lipid-modified Hedgehog signal in soluble form. Genes Dev 26, 1312-1325.

Ganassi, M., Badodi, S., Polacchini, A., Baruffaldi, F., Battini, R., Hughes, S. M., Hinits, Y. and Molinari, S. (2014). Distinct functions of alternatively spliced isoforms encoded by zebrafish mef2ca and mef2cb. Biochimica et biophysica acta 1839, 559-570.

Goishi, K., Lee, P., Davidson, A. J., Nishi, E., Zon, L. I. and Klagsbrun, M. (2003). Inhibition of zebrafish epidermal growth factor receptor activity results in cardiovascular defects. Mech Dev 120, 811-822.

Heiden, T. C., Struble, C. A., Rise, M. L., Hessner, M. J., Hutz, R. J. and Carvan, M. J., 3rd (2008). Molecular targets of 2,3,7,8-tetrachlorodibenzo-p-dioxin (TCDD) within the zebrafish ovary: insights into TCDD-induced endocrine disruption and reproductive toxicity. Reprod Toxicol 25, 47-57.

Hollway, G. E., Maule, J., Gautier, P., Evans, T. M., Keenan, D. G., Lohs, C., Fischer, D., Wicking, C. and Currie, P. D. (2006). Scube 2 mediates Hedgehog signalling in the zebrafish embryo. Dev Biol 294, 104-118.

Hsieh, M., Lee, D., Panigone, S., Horner, K., Chen, R., Theologis, A., Lee, D. C., Threadgill, D. W. and Conti, M. (2007). Luteinizing hormone-dependent activation of the epidermal growth factor network is essential for ovulation. Mol Cell Biol 27, 19141924.

Huang, Y., Zhao, Y., Yu, Y., Li, R., Lin, S., Zhang, C., Liu, P. and Qiao, J. (2015). Altered amphiregulin expression induced by diverse luteinizing hormone receptor reactivity in granulosa cells affects IVF outcomes. Reprod Biomed Online 30, 593-601. 
bioRxiv preprint doi: https://doi.org/10.1101/745018; this version posted August 22, 2019. The copyright holder for this preprint (which was not certified by peer review) is the author/funder, who has granted bioRxiv a license to display the preprint in perpetuity. It is made available under aCC-BY 4.0 International license.

Ciano et al

Jamnongjit, M., Gill, A. and Hammes, S. R. (2005). Epidermal growth factor receptor signaling is required for normal ovarian steroidogenesis and oocyte maturation. Proc Natl Acad Sci U S A 102, 16257-16262.

Mains, P. E., Sulston, I. A. and Wood, W. B. (1990). Dominant maternal-effect mutations causing embryonic lethality in Caenorhabditis elegans. Genetics 125, 351-369.

Marlow, F. L. (2010). Maternal Control of Development in Vertebrates: My Mother Made Me Do It! San Rafael (CA): Morgan \& Claypool Life Sciences.

Miettinen, P. J., Berger, J. E., Meneses, J., Phung, Y., Pedersen, R. A., Werb, Z. and Derynck, R. (1995). Epithelial immaturity and multiorgan failure in mice lacking epidermal growth factor receptor. Nature 376, 337-341.

Naganawa, Y. and Hirata, H. (2011). Developmental transition of touch response from slow muscle-mediated coilings to fast muscle-mediated burst swimming in zebrafish. Dev Biol 355, 194-204.

Ningappa, M., So, J., Glessner, J., Ashokkumar, C., Ranganathan, S., Min, J., Higgs, B. W., Sun, Q., Haberman, K., Schmitt, L., et al. (2015). The Role of ARF6 in Biliary Atresia. PLoS One 10, e0138381.

Peyton, C. and Thomas, P. (2011). Involvement of epidermal growth factor receptor signaling in estrogen inhibition of oocyte maturation mediated through the $\mathrm{G}$ proteincoupled estrogen receptor (Gper) in zebrafish (Danio rerio). Biol Reprod 85, 42-50.

Richani, D. and Gilchrist, R. B. (2018). The epidermal growth factor network: role in oocyte growth, maturation and developmental competence. Hum Reprod Update 24, 1-14.

Richani, D., Sutton-McDowall, M. L., Frank, L. A., Gilchrist, R. B. and Thompson, J. G. (2014). Effect of epidermal growth factor-like peptides on the metabolism of in vitromatured mouse oocytes and cumulus cells. Biol Reprod 90, 49.

Schall, K. A., Holoyda, K. A., Grant, C. N., Levin, D. E., Torres, E. R., Maxwell, A., Pollack, H. A., Moats, R. A., Frey, M. R., Darehzereshki, A., et al. (2015). Adult zebrafish intestine resection: a novel model of short bowel syndrome, adaptation, and intestinal stem cell regeneration. Am J Physiol Gastrointest Liver Physiol 309, G135-145.

Sibilia, M. and Wagner, E. F. (1995). Strain-dependent epithelial defects in mice lacking the EGF receptor. Science 269, 234-238.

Sugimura, S., Ritter, L. J., Rose, R. D., Thompson, J. G., Smitz, J., Mottershead, D. G. and Gilchrist, R. B. (2015). Promotion of EGF receptor signaling improves the quality of low developmental competence oocytes. Dev Biol 403, 139-149.

Threadgill, D. W., Dlugosz, A. A., Hansen, L. A., Tennenbaum, T., Lichti, U., Yee, D., LaMantia, C., Mourton, T., Herrup, K., Harris, R. C., et al. (1995). Targeted disruption of mouse EGF receptor: effect of genetic background on mutant phenotype. Science 269, 230-234.

Van Der Kraak, G. and Lister, A. L. (2011). The inhibitory control of oocyte maturation in the zebrafish (Danio rerio): the role of the $G$ protein-coupled estrogen receptor and epidermal growth factor. Biol Reprod 85, 6-8.

Wang, Y. and Ge, W. (2004). Cloning of epidermal growth factor (EGF) and EGF receptor from the zebrafish ovary: evidence for EGF as a potential paracrine factor from the oocyte to regulate activin/follistatin system in the follicle cells. Biol Reprod 71, 749-760.

Westerfield, M. (2000). The Zebrafish Book - A guide for the laboratory use of zebrafish (Danio rerio): University of Oregon Press.

Zhao, Y. and Lin, S. (2013). Essential role of SH3-domain GRB2-like 3 for vascular lumen maintenance in zebrafish. Arterioscler Thromb Vasc Biol 33, 1280-1286. 
bioRxiv preprint doi: https:/doi.org/101101/745018; this version posted August 22 2019. The copyright holder for this preprint (which was not certified by peer review) is the author/funder, who has granted bioRxiv a license to display the preprint in perpetuity. It is made available under aCC-BY 4.0 International license.

Ciano et al

\section{Author contributions}

346 SMH and SAS conceived the project and obtained finance. MC performed all experiments and analysis.

347 PRK provided advice. SMH and MC wrote the paper with input from other authors.

\section{Acknowledgements}

350 We are grateful to Giorgia Bergamin and all members of the Hughes lab for advice, and to Bruno Correia da 351 Silva and his staff for care of the fish.

\section{Financial Disclosure Statement}

$354 \mathrm{SMH}$ is a member of the Medical Research Council Scientific Staff with Programme Grant MR/N021231/1

355 support. The funders had no role in study design, data collection and analysis, decision to publish, or 356 preparation of the manuscript.

\section{Competing interests}

359 The authors have declared that no competing interests exist. 
bioRxiv preprint doi: https://doi.org/10.1101/745018; this version posted August 22, 2019. The copyright holder for this preprint (which was not certified by peer review) is the author/funder, who has granted bioRxiv a license to display the preprint in perpetuity. It is made available under aCC-BY 4.0 International license.

Ciano et al

$\operatorname{Pg} 10$

\section{Figure Legends}

\section{Figure 1 Survival of embryos from egfra ${ }^{+/ k g 134}$ and sibling females.}

A, B. Survival curves for embryos from the indicated crosses. The single F1 female obtained (designated $\alpha$ ) was crossed repeatedly and survival of progeny monitored every twelve hours (A). Three separate F2 egfra ${ }^{+/ k g 134}$ females (designated $\beta, \gamma$ and $\delta$ ) were also tested (B). Note that lays from wild type (wt) sibling females crossed with wt or heterozygous egfra ${ }^{+/ k g 134}$ males survive, whereas lays from heterozygous egfra ${ }^{+/ k g 134}$ females die, irrespective of the partner male genotype.

\section{Figure 2 Heterozygous maternal effect may arise from maternal egfra expression in early embryos.}

A. In situ mRNA hybridisation for antisense (left) and sense (right) egfra probes at 32 cell stage, after gastrulation and at $1 \mathrm{dpf}$. Bars $=500 \mu \mathrm{m}$. Note abundant expression at 32 cells, prior to zygotic genome activation and widespread but declining mRNA until $24 \mathrm{hpf}$. B. Representative timelapse imaging of single progeny of a wild type sibling female (left) and three maternal effect phenotypes (right) from egfra ${ }^{+/ k g 134}$ females crossed to egfra ${ }^{+/ k g 134}$ males. As all embryos from the wild type female appeared wild type the progeny were not individually genotyped and are therefore designated egfra ${ }^{+/ ?}$. All embryos from the carrier female showed growth retardation, with a moderate group characterised by cardiac oedema (arrow 1) and curvature at the tail tip (arrow 2), of which a zygotic mutant is shown. A severe group presented with a beanshaped yolk at $18 \mathrm{hpf}$ that, by the end of day 1, showed curvature of the trunk and tail (arrow 3), which persisted even after a day outside of the chorion; a zygotic wild type is shown. A very severe group had poor tailbud formation at $18 \mathrm{hpf}$, cardiac oedema (arrow 4) and failure of tail development (arrow 5) during day 1. Such embryos die by $2 \mathrm{dpf}$ and the one shown was therefore not genotyped. All three phenotypes were also obtained from egfra ${ }^{+/ k g 134}$ females crossed to egfra ${ }^{+/+}$males.

\section{Figure 3 F3 egfra ${ }^{+/ k g 134}$ and wild type siblings swim similarly.}

A. Images extracted from burst response videos of F3 2 dpf sibling wt (A-A2) and egfra ${ }^{+/ k g 134}$ (B-B2) larvae and $5 \mathrm{dpf}$ sibling wt (C-C2) and egfra ${ }^{+/ k g 134}$ (D-D2) larvae. Timepoints are shown in milliseconds (ms). Arrows indicate the plot of the tracking analysis with the $X$ and $Y$ coordinates, the red asterisk in the plot indicates the start point of the fish, black symbol: WT fish, blue symbols: egfrat/kg134 fish. Bar $5 \mathrm{~mm}$. B. Diagram to illustrate how measurement of Velocity was performed. C. Motility of $2 \mathrm{dpf}$ and $5 \mathrm{dpf} \mathrm{F3} \mathrm{egfra+/kg134}$ and wt sibling larvae were compared. No difference was found at either age ( $2 \mathrm{dpf} N=22 / g r o u p$ from 2 crosses, mean velocity $p=0.68$ and maximum velocity $p=0.12 ; 5 \mathrm{dpf} \mathrm{N}=11 /$ group from 2 crosses, mean velocity $p=0.21$ and maximum velocity $p=0.32$, Mann-Whitney $U$ test).

\section{Supplementary Table 1 Primers for genotyping}

HRMA primers

5'-CCCGATAGCTTACAAACGCA-3'

5'-GCCGTTTCACAATAGTCCTACC-3'

Sequencing primers

\section{5'-GCGATGTTCCCAAATCATTTTCC-3'}


Fig. 1

A

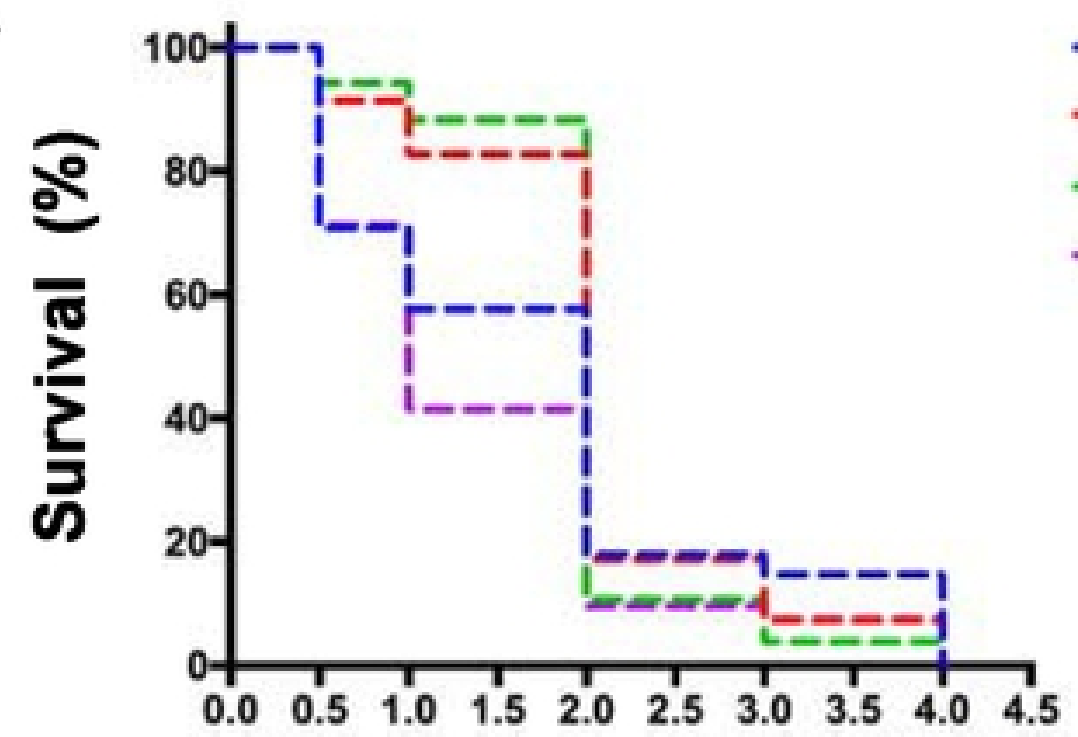

- F1 a 우 egfra ${ }^{+/ / k g 134} \times \delta$ egfrat/kg134 $n=341$ (1)

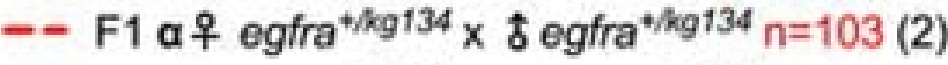

- - F1 a 우 egfrat/kg134 $\times$ s egfrat/kg134 $n=209$ (3)

- - F1 a ㅇ egfra ${ }^{+/ k g 134} \times$ o egfra ${ }^{+/ k g 134} n=91$ (4)

Age (dpf)

bioRxiv preprint doi: https://doi.org/10.1101/745018; this version posted August 22, 2019. The copyright holder for this preprint (which was not certified by peer review) is the author/funder, who has granted bioRxiv a license to display the preprint in perpetuity. It is made

B

-- F2 $\beta$ 우 egfra ${ }^{+/ k g 134} \times$ o egfra ${ }^{+/ k g 134} \mathrm{n}=212$ (5)

... $\mathrm{F} 2 \boldsymbol{\beta}$ 우 egfra ${ }^{+/ k g 134} \mathrm{X}$ 。 $\mathrm{wt} n=128$ (6)

- - F2 Y우 egfra ${ }^{\text {t/kg134 }} \times$ o egfra $^{+/ k g 134} \mathrm{n}=138$ (5)

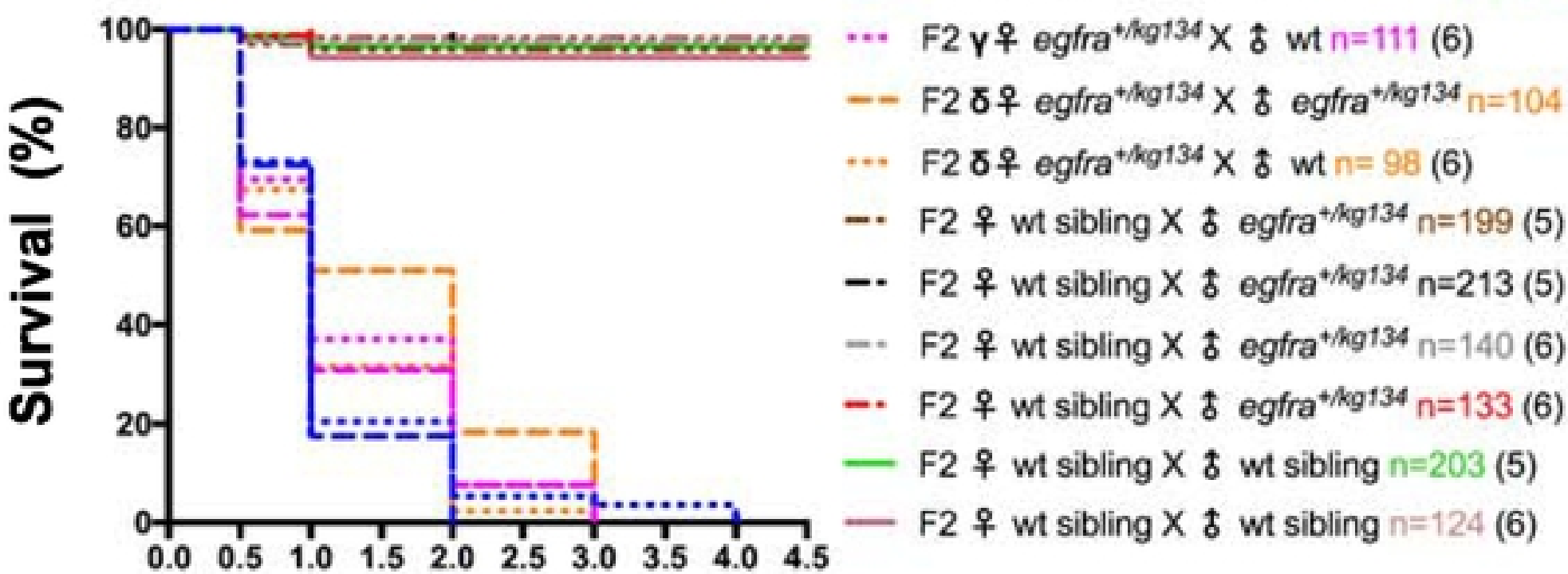

Age (dpf) 
Fig. 2

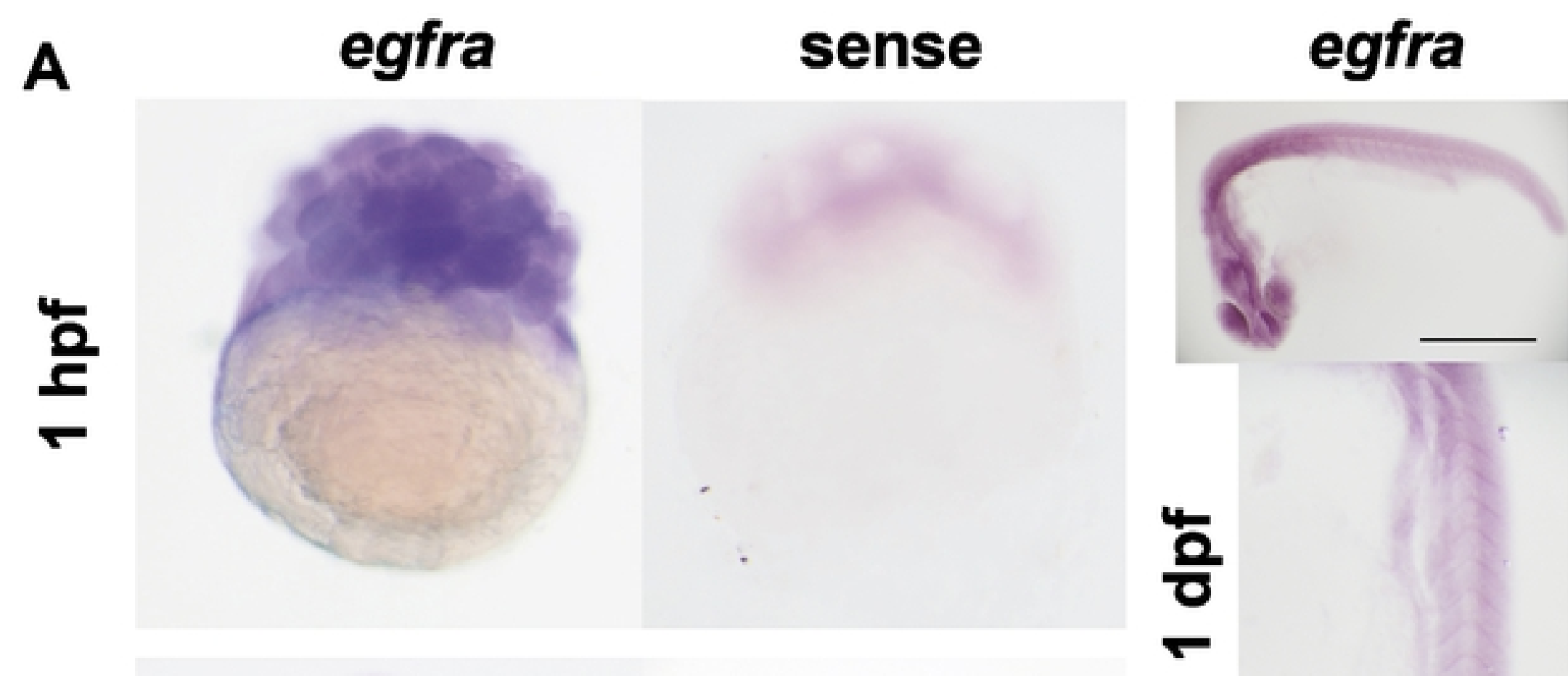

bioRxiv preprint doi: https://doi.org/10.1101/745018; this version posted August 22, 2019. The copyright holder for this preprint (which was not certified by peer review) is the author/funder, who has granted bioRxiv a license to display the preprint in perpetuity. It is made

몸

B
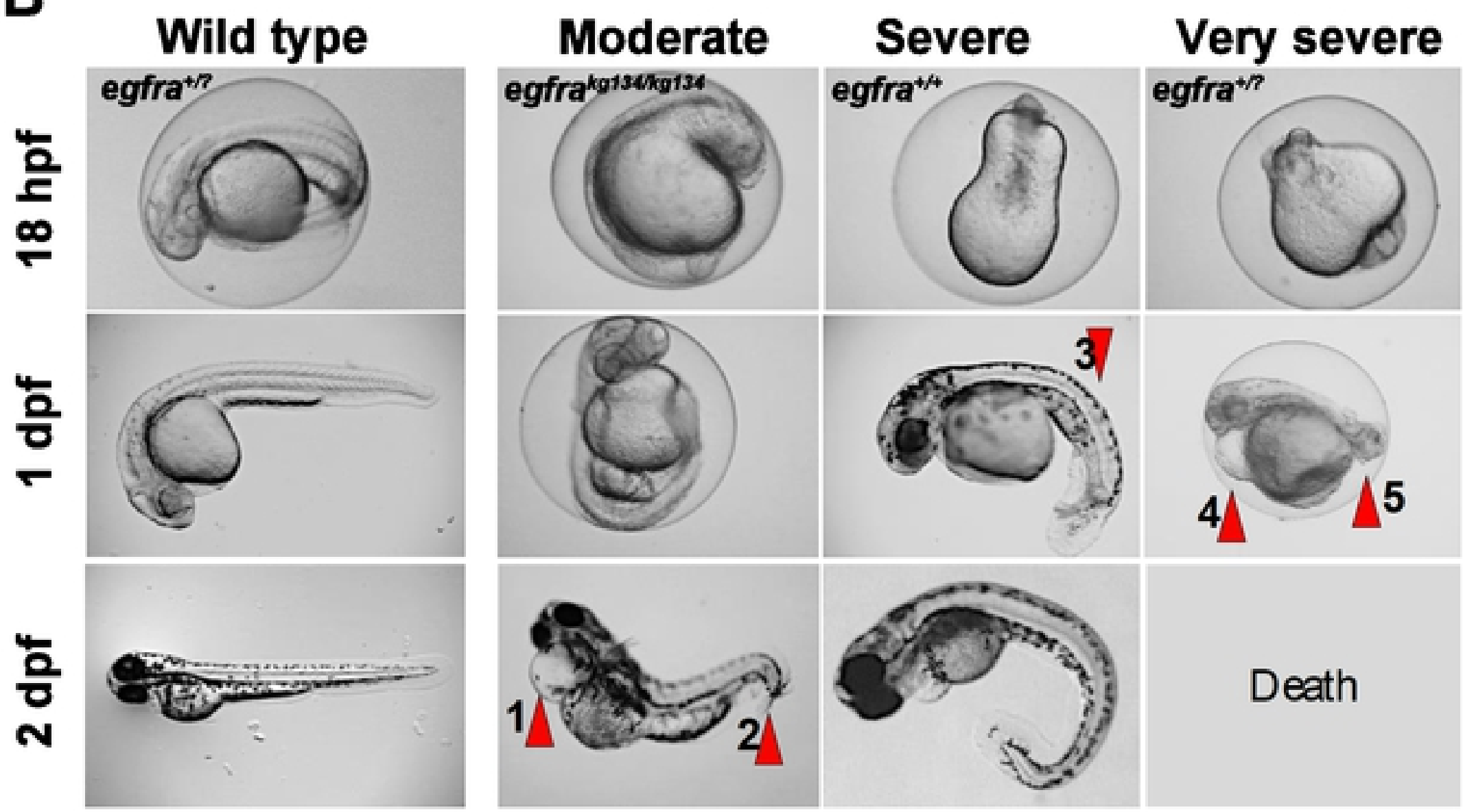


\section{Fig 3}

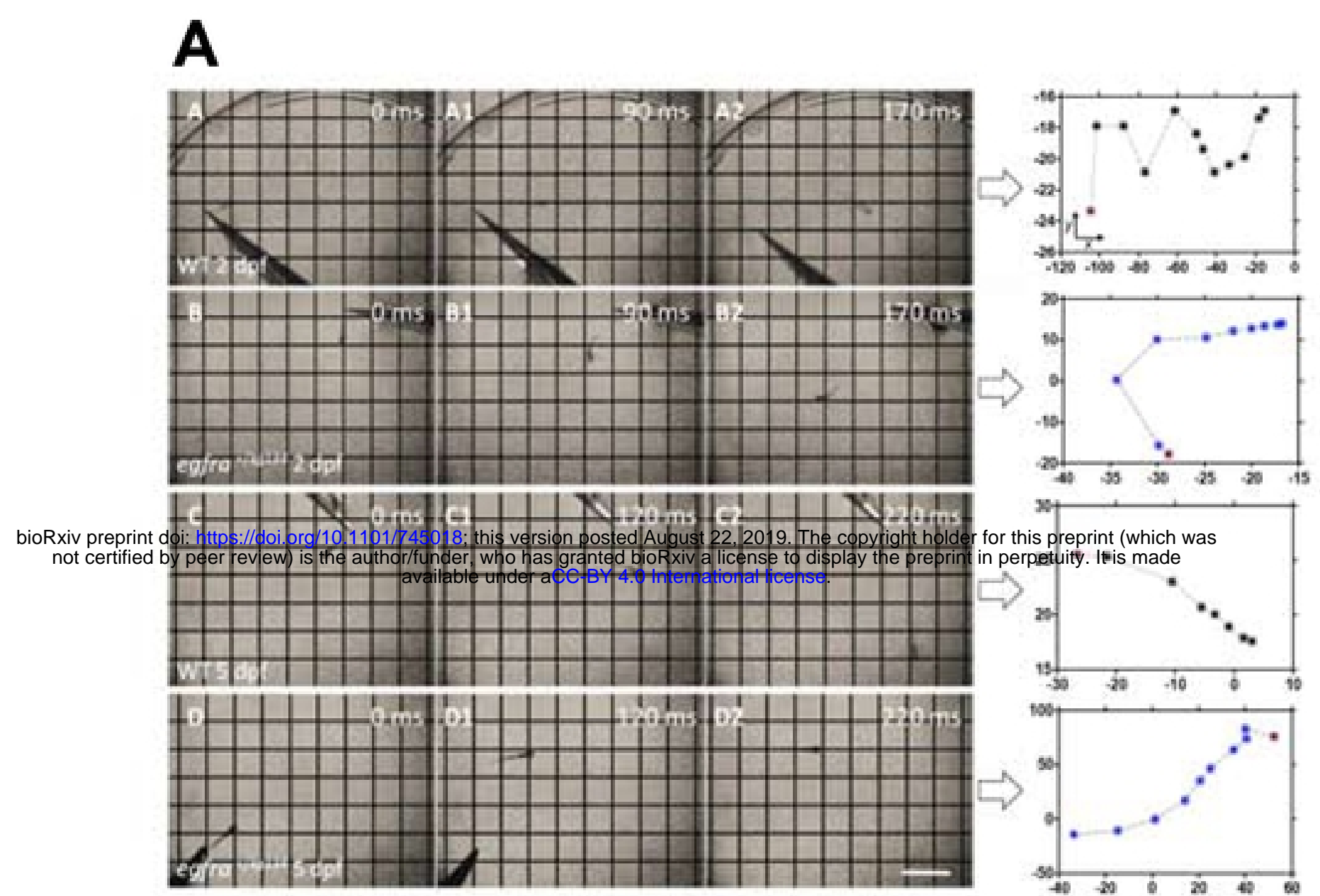

B

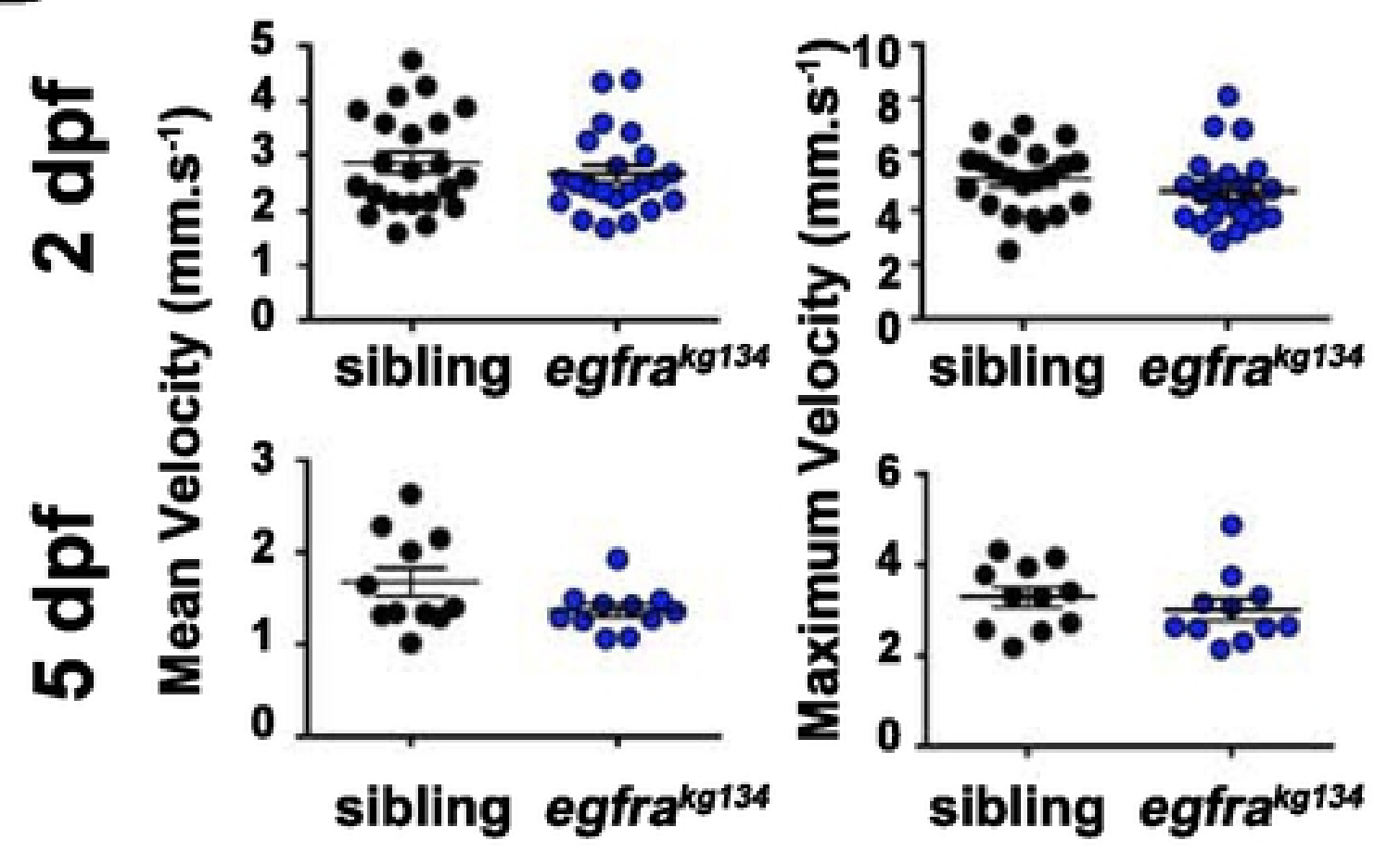

